\title{
Pemahaman Kata GO'EL Dalam Kitab Rut
}

\author{
Ponco Mujiono Basuki \\ Evangelical Theological Seminary of Indonesia - Surabaya \\ E-mail: poncomujiono@sttii-surabaya.ac.id
}

\begin{abstract}
God is fully sovereign over the life of His people and He allows everything happening naturally in everyday man experience. But it will be real when examined more deeply, that in all the events of this life, God works to achieve His plan. Practically-theologically, the law about go'el in Israel's history is showing about the love and care of God in the Israel's life. His people and proof of God's loyalty to His promises and plans. As go'el Boas also had to take Ruth to be his wife in order to uphold the name of the dead person, namely Mahlon, Ruth's husband, through the son who was born to Ruth from Boaz. Thus the name of Mahlon did not disappear from among the Israelites.
\end{abstract}

Keywords: Go 'El, Ruth, Sovereign, Maintenance

\section{PENDAHULUAN}

Kesetiaan Allah dalam keberlanjutan hidup Israel merupakan satu tema yang terus dikemukakan dari waktu ke waktu. Sejarah dan perjalanan hidup Israel penuh dengan campur tangan Allah, yang tujuan untuk memelihara dan membawa Israel sesuai rencana Allah dimasa depan.

Pemanggilan Abraham dari Urkasdim dan penggenapan janji tentang satu bangsa yang besar telah digenapinya secara ajaib. Dari seorang wanita tua yang mandul dan telah mati pucuk, diturunkan 12 suku Israel. Penindasan selama 400 an tahun di Mesir tidak membuat Israel punah.

Perjalanan menuju Kanaan, tanah Perjanjian Allah; justru menunjukkan betapa Allah senantiasa bertanggung-jawab atas hidup dan kehidupan Israel. Satu-satunya alasan bagi Allah untuk membinasakan Israel sewaktu dalam perjalanan di padang gurun adalah ketidak-percayaan Israel atas kesetiaan Allah untuk memeliharakan hidup mereka. Namun demikian, Allah menumbuhkan generasi baru yang lahir di padang gurun dan membawanya masuk ke Kanaan menggenapkan janjiNya kepada Abraham dimasa lampau.

Selama di tanah Perjanjian, tanah yang berlimpah dengan susu dan madu; kesetiaan Allah terus dinyatakan di tengah persaingan dan tekanan bangsa-bangsa lain. Bahkan selama Israel berdiam ditanah Kanaan inilah penggenapan janji demi janji dari Allah begitu nyata, dan Kerajaan Israel mencapai masa kejayaannya.

Masa raja-raja sesudah masa Raja Salomo menunjukkan kemerosotan moral yang sangat serius, baik di Kerajaan Utara maupun Kerajaan Selatan; yang berakhir dengan pembuangan di Babilonia.
Yang dibawa ke pembuangan sudah hilang harapan, dan yang tertinggal di Yerusalem hidup dalam kehinaan yang memalukan sebagai umat Tuhan.

Selama periode ini seolah masa depan Israel sudah habis. Tetapi pada tahun ke 70 masa pembuangan, penguasa baru; Arthasasta, mengeluarkan dekrit tentang pemulangan semua orang buangan kenegerinya masing-masing (Ezra 1:1-4). Israel kembali dari pembuangan, kehidupan beribadah kepada Allah direstorasi, bait Allah dibangun lagi dan tembok kota Yerusalem dibangun kembali.

Dengan ini identitas Israel sebagai bangsa kepunyaan Allah yang berdaulat kembali dinyatakan. Dalam babak ini, sekali lagi ditunjukkan akan kesetiaan Allah dalam memelihara hidup umatNya. Dan hal semacam ini akan terus berlangsung sampai akhir zaman ketika Allah menggenapkan semua janji dan rencana-Nya.

Dalam kitab Yosua dan Hakim-Hakim, fokusnya adalah negeri yang dijanjikan Allah kepada keturunan Abraham. Dalam kitab Rut, fokusnya adalah 'benih' yang dijanjikan, yang secara khusus benih itu adalah pribadi yang akan lahir dari suku Yehuda untuk memerintah umatNya. Kitab Rut menyoroti kedaulatan Allah dalam menggunakan manusia sebagai alat untuk mencapai rencanaNya. ${ }^{1}$

\footnotetext{
${ }^{1}$ Roy B. Zuck. A Biblical Theology Of The Old
} Testament. Penerbit Gandum Mas. Malang. 2005. P. 204 


\section{Keluarga Elimelekh Meninggalkan Betlehem}

Allah berdaulat atas kehidupan umat, dan Ia mengijinkan segala sesuatu terjadi secara natural dalam pengalaman sehari-hari manusia. Namun bila ditelaah lebih dalam akan nyata bahwa didalam semua peristiwa hidup Allah turut bekerja untuk mencapai rencanan-Nya.

Elimelekh adalah seorang imam yang hidup untuk melayani Tuhan. Ia bersama Naomi, istrinya; dan kedua anaknya laki-laki; Mahlon dan Kilyon, tinggal di Betlehem Yehuda. Betlehem sendiri artinya house of breed yang bermakna bahwa keluarga ini berada ditempat yang berlimpah dengan makanan.

Namun ketika paceklik melanda wilayah ini, seluruh penduduk mengalami kelaparan. Dalam situasi ini Elimelekh dan keluarganya berinisiatif untuk pergi ke tanah asing demi makanan, meninggalkan persekutuan dengan Tuhan dan umatNya. Sangat ironis sekali.

Secara ekonomi keadaan keluarga Elimelekh di tanah Moab mungkin lebih baik dibanding ketika berada di Betlehem. Namun Alkitab menyatakan bahwa justru di Moab, saat keluarga Elimelekh mendapatkan apa yang dicarinya; mereka mengalami kerugian besar.

Elimelekh si kepala rumah tangga mati. Kedua anaknya; Mahlon dan Kilyon; mengambil wanita asing yang ada di sekitarnya sebagai istri. Suatu tindakan yang dilarang oleh hukum Musa untuk dilakukan oleh orang Israel. Kemudian Mahlon dan Kilyon mati sebelum memiliki anak sebagai penerus nama keluarga.

Ini menjadi masalah serius bagi bagi keluargakeluarga Israel berkaitan dengan kelanjutan nama keluarga. Kematian Mahlon dan Kilyon sendiri menjadikan Naomi tidak lagi memiliki tempat untuk berpijak.

\section{Naomi Kembali ke Betlehem}

Selagi masih di Moab dan mengalami kehilangan besar-besaran, Naomi mendengar bahwa Allah telah memberkati serta mengubah keadaan umat-Nya di Israel, dan ia berniat pulang kembali.

Dalam perjalanan Naomi mendesak kedua menantunya untuk kembali kepada keluarganya, bangsanya, dan allahnya. Orpa mengikuti saran Naomi dan pulang ke daerah asalnya. Rut bersikukuh untuk tetap mengikuti Naomi kemanapun pergi dan menyatakan bahwa: “. . . bangsamulah bangsaku dan Allahmulah Allahku." (Rut 1:17). Suatu pernyataan identifikasi dari Rut 'si wanita asing' terhadap Yahweh dan Israel umat-Nya.

Sesampainya di Betlehem seluruh kota gempar dan menyebut nama Naomi. Tetapi Naomi sendiri tidak mau disapa dengan nama itu dan minta dipanggil dengan nama Mara yang artinya 'pahit' sebab katanya:" . . . sebab Yang Maha Kuasa telah melakukan banyak yang pahit kepadaku. . . Dengan tangan yang penuh aku pergi, tetapi dengan tangan yang kosong Tuhan memulangkan aku. . . Tuhan telah naik saksi menentang aku dan Yang Maha Kuasa telah mendatangkan malapetaka kepadaku."

\section{Pertemuan Boas dengan Rut}

Datang dalam keadaan kekurangan secara ekonomi, mengharuskan Rut bekerja keras memungut sisa-sisa bulir gandum sebagai wujud tanggung jawab kehidupan untuk dirinya sendiri maupun untuk Naomi mertuanya.

Menurut hukum Musa, para pekerja secara sengaja harus menyisakan bulir-bulir gandum bagi anak yatim dan janda-janda (Im. 19:9-10; Ul.24:19), yang biasanya memungut sisa-sisa itu dibelakang para pekerja yang sedang memanen.

Kehadiran Rut di ladang Boas terjadi secara natural, seperti pada lazimnya seseorang pencari sisa-sisa bulir gandum mendatangi ladang yang sedang dipanen. Pasal 2:3 menyatakan bahwa 'kebetulan Rut pergi ke ladang di ladang milik Boas,' yang ternyata masih ada hubungan kerabat dengan Naomi (ay.1).

Rut tidak bermaksud untuk pergi ke ladang tertentu, namun 'kebetulan' ia pergi keladang milik Boas. Apa yang nampak sebagai peristiwa kebetulan, jika dilihat dari seluruh kisah merupakan bagian dari pengaturan Allah. ${ }^{2}$ Terlihat betapa tangan Allah bekerja dalam menuntun Rut ke tanah milik Boas. ${ }^{3}$

Ayat-ayat selanjutnya menyatakan bahwa Rut seperti mendapat perhatian khusus dan istimewa dari Boas walaupun ia tahu bahwa Rut adalah perempuan asing yang datang dari Moab, yang dalam pandangan orang Israel dinilai rendah.

Pernyataan Charles F. Pfeiffer di atas paling tidak sedang memberi bukti awal; dalam kasus Rut dan Naomi; tentang kesetiaan dan konsistensi Allah terhadap rencana-Nya di masa depan.

Melihat kenyataan bahwa Rut mendapatkan tempat di hati Boas serta fakta bahwa Boas adalah 'salah seorang kerabat Naomi' yang punya hak sebagai 'penebus' maka Naomi mengatur bagaimana caranya agar Rut bisa mendapatkan tempat perlindungan.

Dalam pasal 3:1-2 Naomi berkata bahwa alangkah baiknya jika ia mencarikan tempat perlindungan bagi Rut, dan bukankah Boas adalah kerabatnya? Yang dimaksudkan adalah bahwa Naomi akan mengatur pernikahan Rut, dan dengan mengingat kebiasaan levirat, Naomi mengambil

\footnotetext{
${ }^{2}$ Charles F. Pfeiffer, Everett F. Harrison. The
} Wycliffe Bible Commentary. Penebit Gandum Mas. Malang. 2004. P. 727.

\footnotetext{
${ }^{3}$ Yayasan Misi OMF. Tafsiran Alkitab Masa Kini I.
} BPK Gunung Mulia. Jakarta. 1982. p. 432. 
keputusan untuk mendekati Boas. Namun rencana Naomi tidak berjalan mulus.

Dalam ayat 12 Boas mengatakan bahwa masih ada seorang 'penebus' yang lebih dekat dari pada dirinya. Boas hanyalah seorang keponakan dari Elimelekh. Sekalipun ia bersedia mengambil kedudukan sebagai go'el (penebus), ia bersikukuh untuk membiarkan orang yang lebih dekat itu memutuskan apakah ia mau mengambil tanggung jawab itu atau tidak. ${ }^{4}$

Lawrence O. Richards menuliskan bahwa the story of Rut also illustrates the meaning of the Hebrew word ga'al, wich means to "play the part of kindman." In Old Testament Law, a near relative had the right to act on behalf of a person in trouble or in danger. When person or possessions were grip of hostile power, the kinsman might act to redeemer (to win release and freedom). The marriage of Boaz to Ruth involved buying back Naomi's family land,and meant that their son would carry on Naomi's family line. ${ }^{5}$

Dalam ayat-ayat selanjutnya, ada percakapan seperti tawar menawar sehubungan dengan tanggung jawab untuk menebus tanah milik Naomi dan menegakkan nama orang yang sudah mati yakni Mahlon, dengan mengambil janda dari Mahlon yaitu Rut. Mendengar penjelasan ini 'penebus' pertama melepaskan haknya dan menyerahkannya kepada Boas. Sampai pada babak ini semakin terlihat dengan jelas tentang campur tangan Allah dalam membuktikan kesetiaan atas semua janji dan rencana-Nya.

\section{Makna GO'EL Menurut Kitab Rut}

Dalam kitab Rut pasal 3, Boas; seorang pria tua yang kaya; diperkenalkan sebagai salah satu kerabat Naomi yang juga bertanggung jawab sebagai penebus bagi Naomi dan keluarganya. Perintah Naomi kepada Rut untuk datang ke tempat pengirikan Boas pada malam hari tidaklah dapat dipersalahkan menurut adat istiadat, bahkan ketika ia menyingkapkan sedikit jubah Boas yang berfungsi sebagai selimut, untuk menyelimuti dirinya sebagai tanda permohonan agar Boas mau menjadi 'penebus'nya. ${ }^{6}$

Dalam kitab Ulangan 25:5-10 disebutkan bahwa disebutkan bahwa apabila ada seorang lakilaki meninggal tanpa memiliki anak laki-laki, maka janda laki-laki itu tidak boleh menikah dengan orang lain diluar lingkungan keluarga. Iparnya; saudara laki-laki dari almarhum suaminya; berkewajiban melakukan perkawinan ipar, yaitu harus mengawini

${ }^{4}$ Charles F. Pfeiffer. p. 730-732.

${ }^{5}$ Lawrence O. Richards. The Teacher's Commentary. Chariot Victor Publishing. Colorado. P. 193

${ }^{6}$ Yayasan Misi OMF. Tafsiran Alkitab Masa Kini I. p. 434. wanita itu dan mengambilnya sebagai istri untuk memberi keturunan /anak laki-laki yang dianggap sebagai anak dari saudaranya yang telah mati.

Dengan demikian nama orang yang sudah mati itu tidak terhapus dari antara orang Israel. Jika saudara laki-laki dari orang yang sudah mati tersebut tidak mau melakukan kewajibannya, maka perkaranya dibawa ke pintu gerbang kota dihadapan tua-tua Isreal. Dan jika tetap tidak mau mengambil tanggung jawab ini, maka wanita itu akan mengambil kasutnya dan meludahi wajahnya didepan tua-tua.

Sistem perkawinan anggan (levirat) dijelaskan dalam kitab Ulangan 25:5-10. Di bawah hukum ini, jika seseorang mati tanpa mempunyai anak laki-laki, saudaranya wajib untuk memperanakkan seorang anak laki-laki melalui jandanya.

Selanjutnya anak laki-laki itu dianggap sebagai pewaris dari saudaranya yang mati, yang menjadi kepala keluarga. Dengan cara ini keluarga tidak akan mudah punah. ${ }^{7}$ Charles C. Ryrie mengatakan bahwa the responsibilities of kinsmanredeemer included : 1) redeeming family property that had changed ownership, and 2) marrying a childless widow to rise up children in her dead husband's name. ${ }^{8}$ Dalam pengertian yang senada, W.E. Vine mengatakan bahwa the kinsman had three right, 1) to purchase back the forfeited inheritance for an Israelite who, owning to poverty, had sold his land, as Boaz did for Ruth (4:3-5), or to hold land in possession for a poor kinsman till the year of jubilee (Leviticus 25:10-28); 2) to ransom his kinsman from bondage to a foreigner (Leviticus $25: 47-49)$; 3) to avenge the death of his slain kinsman, as a point of honor. ${ }^{9}$

Inilah yang sedang dilakukan Naomi melalui Rut, berusaha mendapatkan kembali tanah keluarga yang terjual, dan untuk menegakkan nama Mahlon yang telah mati melalui seorang penebus (go'el) yaitu Boas.

Rupanya perintah inilah yang menjadi dasar diberlakukannya sistem perkawinan levirat di antara orang Isreal, yang masih berlaku hingga zaman Tuhan Yesus. Dalam kitab Matius 22, Markus 12 dan Lukas 20; dikisahkan bahwa orang-orang Saduki yang tidak percaya adanya kebangkitan orang mati mencoba menjebak Yesus dengan pertanyaan yang berdasar dari aturan levirat ini.

${ }^{7}$ Andrew E. Hill, dan John H. Waton. Survay Perjanjian Lama. Penerbit Gandum Mas. Malang. 2004. P. 296-297.

${ }^{8}$ Charles C. Ryrie. Ryrie StudyBible. Moody Press. Chicago. 1994. P. 396.

${ }^{9}$ WE.Vine. Vine's Expository Dictionary Of Old \& New Testament Words. Thomas Nelson Publisher. Nashville, Tennessee. 1997. P. 87. 


\section{Mempertahankan Tanah Warisan Keluarga}

Tanah Perjanjian adalah pusaka yang Tuhan berikan kepada Israel. Sejahtera tidaknya hidup Israel erat kaitannya dengan tanah tersebut. Manakala Israel hidup setia dan berbakti kepada Allah, Ia memberikan kelimpahan panen dan keamanan diseluruh negeri. Tetapi ketika Israel berubah setia kepada Allah, Ia mendatangkan kekeringan, belalang, ataupun bangsa tetangga yang menjarah hasil panen, sehingga Israel mengalami kekurangan pangan.

Dan puncak dari semuanya adalah ketika Allah mengusir Israel keluar dari Tanah Perjanjian melalui raja Nebukadnesar, dan membuangnya ke Babilonia selama 70 tahun sebagai hukuman atas ketidaksetiaan Israel. Sepanjang sejarah Israel, tanah memiliki arti penting. Bahkan perseteruan panjang antara Israel dengan Palestina yang akan terus berlangsung sampai 'masa depan' bermuara pada perebutan dan klaim atas tanah.

Dalam konteks kitab Rut, persoalan tanah tidaklah sebesar persoalan Israel-Palestina. Namun prinsipnya adalah bahwa tanah keluarga jangan dijual kepada orang lain yang bukan keluarga. Apabila tanah sudah dijual kepada orang lain, Imamat 25:23-28 memberikan aturannya sehingga tanah tersebut akan kembali lagi kepada keluarga pemiliknya.

Aturan pertama adalah bahwa kerabat dekat dari keluarga yang menjual tanah tersebut diberi hak menebus tanah itu. Kedua, bila orang tersebut kemudian mampu untuk membeli kembali tanahnya, maka tanah itu harus dikembalikan kepadanya, dengan tanpa membuat kerugian pada pihak yang telah membeli sebelumnya. Ketiga, jika tidak mampu membelinya kembali, maka tanah itu tetap menjadi milik si pembeli sampai pada tahun Yobel, dimana semua tanah dibebaskan dan dikembalikan kepada keluarga pemiliknya.

Penafsiran yang lebih luas mengenai perkawinan anggan ini digabung dengan hak-hak penebusan tanah menyediakan latar belakang hukum untuk kitab Rut. Sebutan go'el diambil dari hukum penebusan tanah dalam Imamat 25:25-31. Menurut hukum ini, tanah yang dijual oleh seseorang dapat ditebus kembali oleh seorang kerabat dekat sehingga tanah itu tetap menjadi milik keluarga. ${ }^{10}$ Boas berkata dihadapan tua-tua Yahudi di pintu gerbang kota dan semua yang hadir disitu:

"Kamu pada hari ini menjadi saksi, bahwa segala milik Elimelekh dan segala milik Kilyon dan Mahlon aku beli dari tangan Naomi; juga Rut perempuan Moab itu, istri Mahlon, aku peroleh menjadi istriku untuk menegakkan nama orang yang telah mati itu atas milik pusakanya. Demikianlah

\footnotetext{
${ }^{10}$ Andrew E.Hill dan John H Waton. P. 297
}

nama orang itu tidak akan lenyap dari antara orang warga kota. Kamulah pada hari ini menjadi saksi."11

Dari pernyataan di atas jelas bahwa Boas menempatkan diri sebagai go'el bagi keluarga Naomi dan seluruh tanah pusakanya.

\section{Memberi Gambaran Tentang Kasih Setia Tuhan}

Lebih lanjut Andrew E.Hill mengatakan bahwa baik hukum penebusan tanah dan perkawinan anggan dimaksudkan untuk melestarikan keluarga dan tanah, yang merupakan soal-soal perjanjian tingkat pertama. Keduanya merupakan ketetapan sosial yang dengannya janjijanji dalam perjanjian Tuhan dapat terwujud.

Go'el menyediakan cara untuk memperoleh kembali berkat-berkat perjanjian yang terancam bahaya, dan dengan demikian dapat menjadi gambaran yang tepat dari kasih karunia Allah. Secara terus menerus Yahweh bertindak sebagai go'el bagi Israel, dan konsep ini menunjuk kepada peranan Kristus dalam Perjanjian Baru. ${ }^{12}$

Parlaungan Gultom menuliskan bahwa Yahweh memberikan bagi janda yang lemah seperti Naomi dan Rut berada dibawah sayap dari "Tuhan, Allah Israel" untuk mendapatkan perlindungan, bahkan memulihakan keadaan Naomi dari kekosongan $(1: 21 ; 3: 17)$ kepada kepenuhan berkat dari janji Tuhan (4:14). Ini semua menunjukkan tentang kasih setia Tuhan kepada perjanjianNya. ${ }^{13}$

Berhubungan dengan kesetiaan Tuhan pada perjanjianNya, maka hesed merupakan istilah yang mengandung implikasi yang sangat sangat jauh jangkauannya. Kitab Rut adalah kitab mengenai hesed baik pada tingkat manusia maupun pada tingkat Ilahi. Hesed Tuhan dinyatakan sebagai faktor yang pada akhirnya akan membawa keberhasilan perkawinan kembali menantu perempuan Naomi, sehingga mau tidak mau hal itu harus diakui dalam penyediaan go'el untuk Rut. ${ }^{14}$

\section{Kesimpulan}

Rentetan peristiwa dalam sejarah kehidupan Naomi dan Rut berlangsung secara natural dan berjalan apa adanya, sebagaimana pengalaman Naomi dan Rut sendiri. Ketika mencermati riwayat Naomi dan Rut seperti yang tertulis dalam kitab Rut, pembaca akan menemukan satu fakta bahwa ada campur tangan Allah dalam semua peristiwa yang kelihatannya berlangsung secara natural itu.
${ }^{11}$ Kitab Rut 4:9-10
${ }^{12}$ Andrew E. Hill. P. 297.
${ }^{13}$ Parlaungan Gultom. Diktat Teology Kitab-Kitab Sejarah PL. STTII Yogyakarta. 2012. p. 51.

$$
{ }^{14} \text { Andrew E.Hill. p. 297-298. }
$$


Pemeliharaan Allah itu begitu nyata. Bukan itu saja, bahkan firman Allah, Alkitab benar-benar dijaga oleh tangan Allah sendiri di dalam bergelut menghadapi tantangan zaman.

Campur tangan Allah dalam sejarah Naomi dan Rut dilakukan sesuai dengan kedaulatan-Nya untuk mencapai rencana-rencana masa depan, baik bagi Naomi dan Rut sendiri maupun bagi Israel sebagai bangsa. Dan hal itu menunjukkan tentang kasih Tuhan kepada umatNya dan kesetiaan Tuhan pada janji-janjiNya.

Keikutsertaan Rut dalam perjalanan Naomi pulang ke Betlehem Yehuda, kehadiran Rut diladang milik Boas untuk memungut sisa-sisa bulir gandum, sikap Boas dan para pekerja terhadap Rut, penolakan 'kerabat yang lebih dekat' dari Boas untuk menebus tanah Elimelekh dan menyerahkan tanggung jawab sebagai penebus itu kepada Boas, merupakan bukti bahwa Allah bekerja dibalik semua peristiwa yang terjadi.

Posisi Boas sebagai go'el bagi Naomi dan Rut memiliki arti bahwa Boas siap membayar tebusan harga tanah Elimelekh yang telah dijual, dan mengembalikannya sebagai milik pusaka bagi keturunan Elimelekh.

Sebagai go'el Boas juga harus mengambil Rut menjadi istrinya demi menegakkan nama orang yang sudah mati, yakni Mahlon suami Rut, melalui anak laki-laki yang kelak dilahirkan oleh Rut dari Boas. Dengan demikian nama Mahlon tidak lenyap dari antara orang Israel.

Secara praktis-teologis, hukum tentang go'el dalam sejarah Israel sedang menunjukkan tentang kasih dan pemeliharaan Allah dalam kehidupan Israel, umatNya; serta bukti kesetiaan Allah terhadap janji-janji dan rencanaNya. Bukan hanya sebatas waktu dalam kehidupan Naomi dan Rut, tetapi juga waktu yang jauh ke depan dalam sejarah hidup Israel, bahkan dalam kehidupan dunia, yakni melalui Yesus Messias yang secara manusia merupakan keturunan Boas dan Rut.

\section{KEPUSTAKAAN}

[1]

Indonesia. 2008.

Alkitab. Lembaga Alkitab

[2] Botterweck, G. Johannes. Theological

Dictionary Of Old Testament. William B.

Michigan.

Eardmans Publishing Company. Grand Rapid.

[3] Gultom, Parlaungan. Diktat Teologi Kitab-

Kitab Sejarah Perjanjian Lama. STTII

Yogyakarta. 2012.

[4] Hill, Andrew E. dan Waton, John H. Survey

Perjanjian Lama. Penerbit Gandum

Mas. Malang. 2004.

[5] Juanda DR. Melayani Kristus Dengan

Karya Tulis. Journal Kerusso. 2017;2(1):45-

54.
[6] Permana S, Lontoh FO, Kusuma S, Verhezen P, Lily T. CORRELATION STUDY

OF CHURCH LEADERSHIP TOWARDS

CHURCH MEMBER COMMITMENT

IN CHRISTIAN CHURCH OF INDONESIA

DARMO SATELIT SURABAYA-

JAWA TIMUR. Sinergi: Jurnal Ilmiah Ilmu

Manajemen. 2018 Sep 27;8(2).

[7] Pfeiffer, Charles F. The Wycliffe Bible

Commentary. Penerbit Gandum Mas.

Malang. 2004.

[8] Richards, Lawrence O. The Theacher's

Commentary. Chariot Victor Publishing.

Colorado

[9] Ryrie, Charles C. Ryrie Study Bible.

Moody Press. Chicago. 1994

[10] Vine, WE. Vine's Expository Dictionary

Of Old \& New Testament Words.

Thomas Nelson Publisher. Nashville, Tennessee. 1997.

[11] Yayasan Misi OMF. Tafsiran Alkitab

Masa Kini. BPK Gunung Mulia. Jakarta. 1982.

[12] Zuck, Roy B. A Biblical Theology of the

Old Testament. Penerbit Gandum Mas.

Malang. 2005. 